\title{
Effect of Physical and Chemical Induced Mutation on Different Character of Gladiolus (Gladiolus grandiflorus L.)
}

\author{
Priyanka Tirkey* and Devi Singh
}
Department of Horticulture (Floriculture and Landscaping), Sam Higginbottom University of Agriculture, Technology and Sciences, Prayagraj 211007, India
*Corresponding author

\begin{tabular}{|l|}
\hline Ke y w o r d s \\
$\begin{array}{l}\text { Gladiolus, Gamma } \\
\text { rays mutagenesis, } \\
\text { Dry Ethyl Methane } \\
\text { Sulphonate (DEMS) }\end{array}$ \\
\hline Article Info \\
\hline $\begin{array}{l}\text { Accepted: } \\
12 \text { October } 2019 \\
\text { Available Online: } \\
10 \text { November } 2019\end{array}$ \\
\hline
\end{tabular}

\section{A B S T R A C T}

\section{Introduction}

Gladiolus (Gladiolus Grandifloras L.) belongs to family Iridaceae and subfamily Ixioidaceae. It is native of South Africa and is attributed as "Queen of bulbous ornamentals" due to its popularity amongst the bulbous ornamentals in the world. Gladiolus is an important cut flower crop which possesses a great potential for export market to European countries especially during winter. In India, gladiolus is commercially grown in west Bengal, Odisha, Uttar Pradesh, Uttarakhand, Tamil Nadu, Punjab, Haryana, Madhya Pradesh, Delhi and 
Rajasthan. Ever increasing demand particularly in cities and towns of India make it an important cut flower which is now available in the Indian markets round the year. Commercial success of any crop depends upon the availability of suitable cultivars to suit the need of the consumers. Present day cultivars have arisen as a result of multicross between various species and varieties which show presence of large amount of variation exists in gladiolus. Other than hybridization, mutation also creates variation. Mutation is a natural process which creates changes in DNA sequences. The genetic variation created is useful because it helps population to survive and change over time. Similarly, experimental mutagenesis permits to increase possibilities of creation of variability with high ornamentation (Cantor et al., 2002) ${ }^{(4)}$. Induced mutation with gamma radiation and chemical mutagens in ornamental plants have been used for genetic changes, high flower yield, disease resistance, early maturity, etc. Gamma rays are known to influence plant growth and development by inducing cytological, genetical, biochemical, physiological and morphogenetic changes in cell and tissues (Abdullah et al., 2009) $^{(1)}$.

Mutations can be induced chemically with alkylating agents, such as ethyl methane sulfonate or by physically by atomic or nuclear (gamma) radiations. The alkyl group of the chemical mutagens reacts with DNA which may change the nucleotide sequence and cause a point mutation, but these compounds induce few chromosome mutations.

Induced mutation with gamma radiation and chemical mutagens in ornamental plants have been used for genetic changes, high flower yield, disease resistance, early maturity, etc. Gamma rays are known to influence plant growth and development by inducing cytological, genetical, biochemical, physiological and morphogenetic changes in cell and tissues (Abdullah et al., 2009) ${ }^{(1)}$. Ethyl methane sulphonate is a very potent mutagen which adds its alkyl group to bases in DNA, causes a mistake and produces point mutations.

The present study was carried out in the Department of Horticulture, Allahabad School of Agriculture, Sam Higginbottom University of Agriculture, Technology and Sciences Prayagraj, during the year 2017-2018. The effect of parents plants which was induced by EMS and gamma rays on various morphological characters of gladiolus with the objective of creating genetic variations in the subjected plant material. The main objectives of the studies are to observe developed new varieties through mutations using chemical and physical mutagens and to observe the different characters of new gladiolus crop.

\section{Materials and Methods}

The corms were used which produced during first year of uniform size $(3.5 \mathrm{~cm}$ to $4.5 \mathrm{~cm})$ observation. During first year we use one physical mutagen (gamma ray) and two chemical mutagens viz., Dry Ethyl Methane Sulphonate (DEMS) and soaked Ethyl Methane Sulphonate (SEMS) were used in the study.

New generated verity produced by mutagen planted in the beds with a spacing of row to row $30 \mathrm{~cm}$ and corm to corm $20 \mathrm{~cm}$ during November 2017 to March 2018.

The Gladiolus (Gladiolus Grandifloras L.) with white prosperity variety was grown with each comprising of treatments replicated thrice. Source of variables were Gamma irradiation level $(2 \mathrm{Kr}, 4 \mathrm{Kr}, 6 \mathrm{Kr}, 8 \mathrm{Kr}, 10 \mathrm{Kr}$ and $12 \mathrm{Kr}$ ); Dry Ethyl Methane Sulphonate (DEMS) (@0.25\%,@0.5\%,@0.75\%,@ 1.0\% and @ 1.25\%); soaked Ethyl Methane 
Sulphonate (SEMS) (@ 0.25\%,@0.5\%,@ $0.75 \%$, @ $1.0 \%$ and @ 1.25\%); and combination of them with control treatment taken as fifty one treatments.

The experiment was laid out according to split plot design by randomizing varieties in main plots and chemical variables in subplots. The treated corms were planted in the well prepared beds of size $1 \times 1 \mathrm{~m}^{2}$ at a spacing of $30 \times 30 \mathrm{~cm}$ and $5-7 \mathrm{~cm}$ deep in soil in Randomized Block Design (RBD) in replicates. Before planting the corms were dipped in 0.2 per cent bavistin for 30 minutes and air dried in shade. Standard package of practices were followed accordingly. For collection of morphological data, 16 plants in a lot per replication were observed and average was calculated. Various growth parameters such as duration of sprouting, sprouting percentage, plant height, floral characters, length of spike, corm weight, diameter, etc. were calculated and analyzed statistically at different period of time.

\section{Results and Discussion}

The new verity produced by EMS treatment and gamma radiation significantly affected the various morphological characters of gladiolus Gladiolus grandifloras L. (white prosperity). The results obtained from the experiment are discussed below:

The data in Table 1 revealed that the new verities produced by gamma rays, SEMS and DEMS significantly delayed the days taken for sprouting of corms as compared to control (13.85 days). The maximum delay was recorded in $\mathrm{T}_{6}$ (23.23 days) which was at par with $\mathrm{T}_{5}$ (22.33 days), $\mathrm{T}_{4}$ (21.10 days) and $\mathrm{T}_{3}$ (19.98 days). The minimum days taken for sprouting of corms were observed in corms in control (13.85 days) followed by $\mathrm{T}_{12}$ (14.24 days), and $\mathrm{T}_{13}$ (14.93 days). The treatment of corms with gamma rays, SEMS and DEMS decreased the sprouting percentage of corms as compared to control. The minimum percentage was recorded with $\mathrm{T}_{6}(75.96 \%)$. The low dose levels of mutagens are responsible for stimulating sprouting substances such as enzymes which are set free by irradiation and play an important role in plant metabolic activities resulting in stimulated plat chromosome structure and cell division, which suppress growth or create lethal effect on the cells of the plant and consequently lead to delay and poor percentage of sprouting and low survival of the plant. The results in the present study are in conformity with the findings of Rather et al., $(2002)^{(14)}$, Srivastava et al., $(2007)^{(16)}$, Kumar et al., (2012) ${ }^{(10)}$ and Berenschot et al., $(2008)^{(2)}$. Khan and Tyagi (2009) ${ }^{(7)}$ attributed the effects of mutagens on the merismetic tissues. The decrease in sprouting at higher doses of the mutagens may also be attributed to disturbances at cellular level including chromosomal damages or due to the effect of both.

Results obtained on maximum Plant height (98.93 cm in 2017-18) recorded in $\mathrm{T}_{0}$ (control) and minimum Plant height $(92.05 \mathrm{~cm}$ in $2017-$ 18) were observed with $T_{6}$ (Gamma Rays $12 \mathrm{Kr}$ ) at $120 \mathrm{DAP}$. Similar findings were reported by Datta $(1990)^{(6)}$ in ornamentals.

The reduction in plant height could also be attributed to the inhibition of growth due to low rate of cell division, decreased amylase activity and increased peroxidase activity (Cherry and Lessman, 1967 in maize) ${ }^{(5)}$. Besides this, production of diffusible growth retarding substances (Mackey, 1951 in barley) ${ }^{(11)}$, inhibitory action of enzymes concerned with the initial growth processes, delay in the onset of first meiosis, change in the specificity of enzymes, inhibition of DNA synthesis and reduction of IAA (Mickaelson, $1968)^{(12)}$ have also been attributed as reasons for the retardation of plant height. Reduced 
growth due to higher doses was also explained differently by different workers. It may be attributed to one or more of the following reasons (i) the increase in growth promoters, (ii) the sudden increase in metabolic status of seeds at certain level of mutagen dose (iii) the increase in destruction of growth inhibitors (iv) drop in the auxin synthesis and (v) decline of assimilation mechanism as reported by Roychowdhury and Tah (2011) ${ }^{(15)}$ in carnation

Results obtained on maximum number of leaves (11.05 in 2017-18) recorded in $T_{1}$ (Gamma Rays 2Kr) and minimum number of leaves (8.45 in 2017-18) were observed with $\mathrm{T}_{16}$ (Soaked EMS @ 1.25\%). Patil (2014) $)^{(13)}$ in clover and Arabidopsis thaliana proposed that in random mutations of characters with definite selection history, each character had varying levels of response for a common mutagen and its doses. The shift in mean values was also found to vary between characters in response to different mutagens. Similar results were obtained by Patil $(2014)^{(13)}$ in gladiolus.

Results obtained on Maximum number of shoot/corm (2.24 in 2017-2018 respectively) were recorded in $\mathrm{T}_{12}$ (SOAKED EMS @ $0.25 \%$ ) and minimum number of shoot/corm (1.24 cm in 2017-2018 respectively) recorded in $\mathrm{T}_{0}$ (control).

According to their data significantly earliest spike initiation 81.15 days were recorded in $\mathrm{T}_{4}$ (Gamma Rays 8Kr) for the years 2017-18 and followed by 81.25 days in $\mathrm{T}_{12}$ (Soaked EMS @ $0.25 \%$ ) for the years $2017-18$ which were at par with each other. However, maximum number of days taken for spike initiation 92.50 days were recorded in $\mathrm{T}_{0}$ (Recommended dose of nutrients through chemical fertilizers) for the years 2017-18.

Earliest days to opening of first florets 85.00 days were recorded in $\mathrm{T}_{12}$ (Soaked EMS @
$0.25 \%$ ) for the years $2017-18$ and followed by 86.50 days in $\mathrm{T}_{13}$ (Soaked EMS @ 0.50\%) for the years 2017-18 which were at par with each other. However, maximum number of days taken for spike initiation 99.50 days were recorded in $\mathrm{T}_{6}$ (Gamma Rays $12 \mathrm{Kr}$ ) for the years 2017-18. The increase or decrease in the number of spikes per plant was significant. However, the decrease in number of spikes may be due to deleterious effects of EMS at higher concentration. These are in conformity with results of Bhajantri and Patil $(2013)^{(3)}$ in gladiolus and Roychowdhury and Tah $(2011)^{(15)}$ in Dianthus. The length of spike also increased with increase in concentration of EMS treatment. Maximum length of spike (cm) $80.90 \mathrm{~cm}$ were recorded in $\mathrm{T}_{12}$ (Soaked EMS @ 0.25\%) for the years 2017-18 and followed by $79.50 \mathrm{~cm}$ in $\mathrm{T}_{7}$ (Dry EMS @ $0.25 \%$ ) for the years 2017-18 which were at par with each other. However, minimum length of spike $(\mathrm{cm}) 74.50 \mathrm{~cm}$ was recorded in $\mathrm{T}_{0}$ (Recommended dose of nutrients through chemical fertilizers) for the years 2017-18. It is evident from the data given in Table $2 b$ that treatment of gladiolus corms with EMS delayed the number of days taken for opening of basal floret in treatment 0.2 per cent EMS. Maximum diameter of the florets $(\mathrm{cm}) 12.35$ $\mathrm{cm}$ was recorded in $\mathrm{T}_{0}$ (Recommended dose of nutrients through chemical fertilizers) for the years 2017-18 and followed by $10.24 \mathrm{~cm}$ in $\mathrm{T}_{12}$ (Soaked EMS @ 0.25\%) for the years 2017-18 which were at par with each other. However, minimum diameter of the florets (cm) $7.26 \mathrm{~cm}$ was recorded in $\mathrm{T}_{6}$ (Gamma Rays $12 \mathrm{Kr}$ ) for the years 2017-18. Maximum number of florets per spike 14.17 were recorded in $\mathrm{T}_{12}$ (Soaked EMS @ 0.25\%) for the years 2017-18 and followed by 14.00 in $\mathrm{T}_{13}$ (Soaked EMS @ 0.50\%) for the years 2017-18 which were at par with each other. However, minimum number of florets per spike 21.71were recorded in $\mathrm{T}_{0}$ (Recommended dose of nutrients through chemical fertilizers) for the years 2017-18. 
Table.1 Effect of chemical and physical mutagens on vegetative parameters of gladiolus

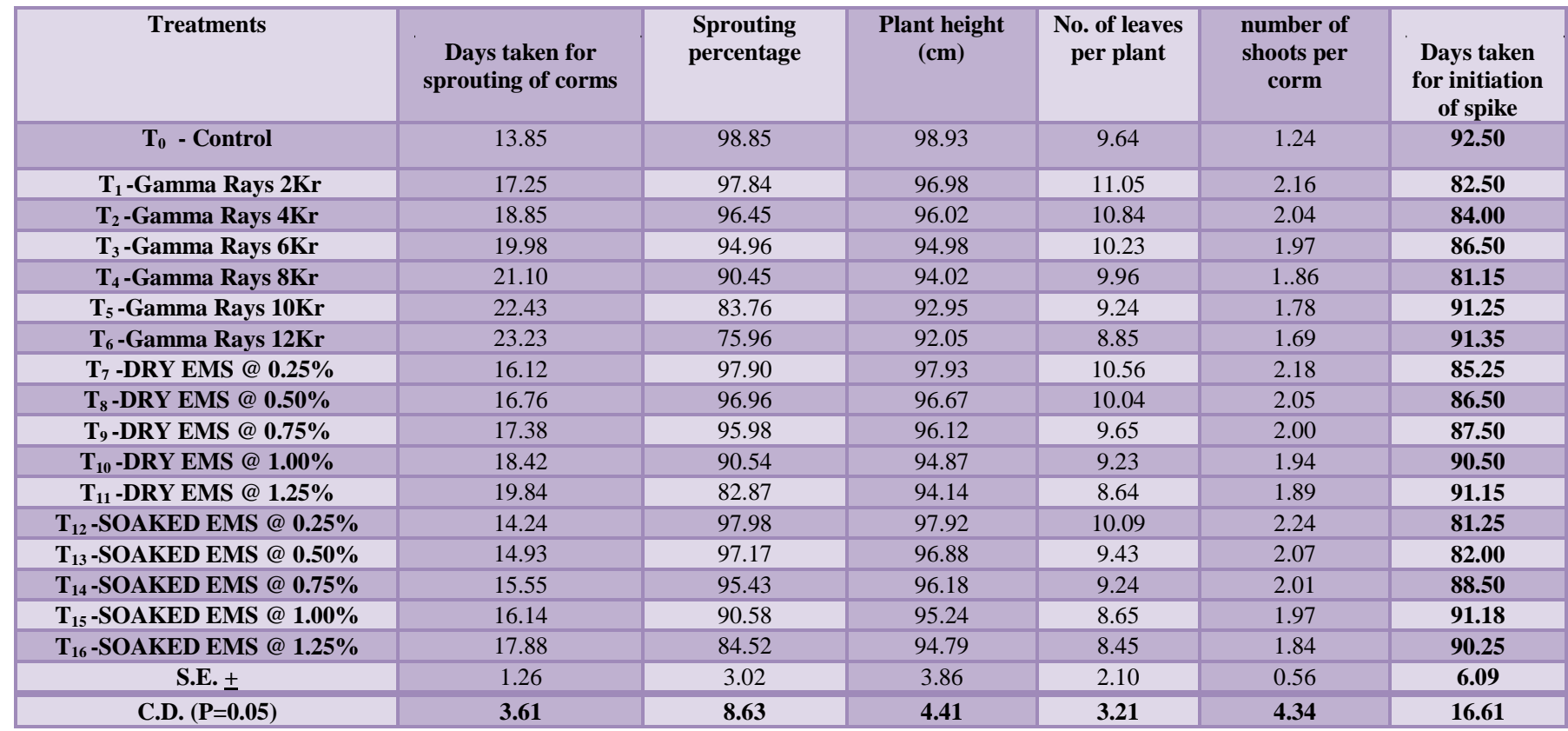

Table.2a Effect of chemical and physical mutagens on flower parameters of gladiolus

\begin{tabular}{|c|c|c|c|c|c|c|}
\hline Treatments & $\begin{array}{c}\text { No. of spike per } \\
\text { plant }\end{array}$ & $\begin{array}{c}\text { Length of spike } \\
(\mathrm{cm})\end{array}$ & $\begin{array}{l}\text { Days to } \\
\text { opening of first } \\
\text { florets }\end{array}$ & $\begin{array}{l}\text { Diameter of the } \\
\text { florets }(\mathrm{cm})\end{array}$ & $\begin{array}{c}\text { Number of } \\
\text { florets per } \\
\text { spike }\end{array}$ & $\begin{array}{l}\text { Days to first } \\
\text { florets } \\
\text { durability }\end{array}$ \\
\hline $\mathbf{T}_{0}$ - Control & 1.42 & 74.50 & 97.50 & 12.35 & 11.15 & 8.47 \\
\hline $\mathbf{T}_{1}$-Gamma Rays $2 \mathrm{Kr}$ & 1.44 & 79.40 & 88.50 & 10.34 & 13.98 & 9.14 \\
\hline $\mathrm{T}_{2}$-Gamma Rays $4 \mathrm{Kr}$ & 1.45 & 80.20 & 89.00 & 9.92 & 13.19 & 10.17 \\
\hline $\mathrm{T}_{3}$-Gamma Rays $6 \mathrm{Kr}$ & $1 . .46$ & 74.60 & 95.50 & 9.44 & 12.71 & 9.67 \\
\hline $\mathrm{T}_{6}$-Gamma Rays $12 \mathrm{Kr}$ & 1.49 & 77.60 & 99.50 & 7.34 & 11.35 & 10.13 \\
\hline T $_{7}$-DRY EMS @ 0.25\% & 1.43 & 79.20 & 86.50 & 10.18 & 14.00 & 10.97 \\
\hline T8-DRY EMS @ 0.50\% & 1.43 & 78.47 & 88.50 & 9.40 & 13.59 & 10.84 \\
\hline T9-DRY EMS @ 0.75\% & 1.44 & 76.05 & 90.50 & 9.05 & 13.16 & 10.78 \\
\hline$T_{10}$-DRY EMS @ 1.00\% & 1.45 & 75.98 & 94.50 & 8.47 & 12.66 & 10.46 \\
\hline$T_{11}$-DRY EMS @ 1.25\% & 1.46 & 75.40 & 95.50 & 7.77 & 11.89 & 9.23 \\
\hline$T_{16}$-SOAKED EMS @ 1.25\% & 1.47 & 75.96 & 97.50 & 8.06 & 11.98 & 9.26 \\
\hline S.E. \pm & 0.89 & 5.84 & 4.65 & 1.04 & 3.16 & 0.89 \\
\hline C.D. $(P=0.05)$ & 3.69 & 12.34 & 9.34 & 2.28 & 4.56 & 1.20 \\
\hline
\end{tabular}


Table.2b Effect of chemical and physical mutagens on vegetative parameters of gladiolus

\begin{tabular}{|c|c|c|c|c|c|c|}
\hline Treatments & $\begin{array}{c}\text { No. of corms per } \\
\text { plant }\end{array}$ & $\begin{array}{l}\text { Diameter of } \\
\text { corm }(\mathbf{c m})\end{array}$ & $\begin{array}{l}\text { No. of } \\
\text { cormels per } \\
\text { plant }\end{array}$ & $\begin{array}{l}\text { Vase life } \\
\text { (days) }\end{array}$ & $\begin{array}{c}\text { No. of } \\
\text { spike/plant }\end{array}$ & $\begin{array}{c}\text { Yield of } \\
\text { spike/ha } \\
\text { (lakh No.) }\end{array}$ \\
\hline$T_{0}$ - Control & 1.35 & 4.17 & 12.46 & 5.05 & 1.51 & 1.07 \\
\hline $\mathrm{T}_{2}$-Gamma Rays $4 \mathrm{Kr}$ & 1.50 & 4.14 & 15.87 & 7.39 & 2.03 & 1.44 \\
\hline $\mathrm{T}_{3}$-Gamma Rays $6 \mathrm{Kr}$ & 1.49 & 4.12 & 15.48 & 6.86 & 1.92 & 1.37 \\
\hline $\mathrm{T}_{4}$-Gamma Rays $8 \mathrm{Kr}$ & 1.47 & 4.10 & 14.51 & 6.44 & $1 . .82$ & 1.29 \\
\hline $\mathrm{T}_{7}$-DRY EMS @ 0.25\% & 1.48 & 4.16 & 16.84 & 9.11 & 2.14 & 1.52 \\
\hline T/ -DRY EMS @ 0.50\% & 1.47 & 4.15 & 15.19 & 8.30 & 2.07 & 1.47 \\
\hline T9-DRY EMS @ 0.75\% & 1.46 & 4.13 & 14.72 & 7.54 & 1.92 & 1.37 \\
\hline$T_{10}$-DRY EMS @ $1.00 \%$ & 1.46 & 4.11 & 13.90 & 6.18 & 1.88 & 1.34 \\
\hline$T_{11}$-DRY EMS @ 1.25\% & 1.45 & 4.09 & 13.47 & 5.56 & 1.79 & 1.27 \\
\hline $\mathrm{T}_{16}$-SOAKED EMS @ $1.25 \%$ & 1.45 & 4.09 & 16.17 & 7.31 & 1.94 & 1.38 \\
\hline S.E. \pm & 1.29 & 3.02 & 1.79 & 1.65 & 0.77 & 15.35 \\
\hline C.D. $(P=0.05)$ & 3.69 & 8.64 & 7.84 & 4.24 & 1.23 & 129.61 \\
\hline
\end{tabular}

Similar stimulated effect on number of florets per spike was observed by Bhajantri and Patil $(2013)^{(3)}$. Maximum durability of first florets 11.40 days were recorded in $\mathrm{T}_{12}$ (Soaked EMS @ $0.25 \%$ ) for the years $2017-18$ and followed by 10.60 days in $\mathrm{T}_{13}$ (Soaked EMS @ 0.25\%) for the years 2017-18 which were at par with each other. However, minimum durability of first florets 8.20 days were recorded in $\mathrm{T}_{0}$ (Recommended dose of nutrients through chemical fertilizers) for the years 2017-18.

Maximum Vase life (days) 10.77 days were recorded in $\mathrm{T}_{12}$ (Soaked EMS @ 0.25\%) for the years 2017-18 and followed by 9.95days in $\mathrm{T}_{13}$ (Soaked EMS @ 0.25\%) for the years 2017-18 which were at par with each other.

However, minimum Vase life (days) 5.13 days were recorded in $T_{0}$ (Recommended dose of nutrients through chemical fertilizers) for the years 2017-18. The significantly maximum number of cormels per plant were recorded in 0.25 per cent SEMS $T_{12}$ (18.21) followed by $\mathrm{T}_{13}$ and $\mathrm{T}_{7}$ while it was minimum in control (12.55). The results are in line with the work of Roychowdhury and Tah (2011) ${ }^{(15)}$. The increase in production of corms and cormels could be due to activation of enzymes and hormones responsible for such growth.

Mutation is recognized as one of the most important technology for the development of new varieties through genetic manipulation. Mutation technique by using ionizing radiations and other mutagens have successfully produced a large number of new promising varieties in different ornamental plants.

Mutation breeding has been successfully applied for varietal improvement of many crop species. About $70 \%$ of the world's mutant varieties have been induced through gammarays. After the observation of the study it was concluded that maximum plants height was observed in control while minimum height observed in the treatment with Gamma Rays $12 \mathrm{Kr}$ while maximum number of leaves and number of shoot per corm were recorded in treatments with Gamma Rays $2 \mathrm{Kr}$ and SOAKED EMS @ 0.25\%)respectively. 


\section{References}

Abdullah, A.L., Johri, E. and Nazir, B.M. (2009). Changes in flower development, chlorophyll mutation and alteration in plant morphology of Curcuma alismatifolia by gamma irradiation. American J. Appl. Sci., 6 : 1436-1439.

Berenschot, A.S., Zucchi, M.I., Neta, A.L. and Quecini, V. (2008). Mutagenesis in Petunia $\mathrm{x}$ hybrid Vilm and isolation of a novel morphological mutant. Braz. J. Plant Physiol., 20(2): 16-27.

Bhajantri, A. and Patil, V.S. (2013). Studies on ethyl methane sulphonate (EMS) induced mutations for enhancing variability of gladiolus varieties (Gladiolus hybridus Hort.) in M1V2 generation. Karnataka J. Agric. Sci., 26(3): 403-407.

Cantor, M., Pop, I. and Kosfoy, S. (2002). Studies concerning the effects of gamma radiation and magnetic sodium deoxyribonucleate, possible chemical mechanism for their biological effects. Nature, Lond., 176 : 919-921.

Cherry Maria, and Lessman Foy Sandor, (1967), studies on concerning the effect of gamma radiation and mutagenic field exposure on gladiolus. J. Central European Agric., 3(4) : 279284.

Datta, S.K., (1990). The role of induced mutation on rose breeding. American Rose Magazine, 30(15): 17-18, 1990.
Khan, M.H. and Tyagi, S.D. (2009). Induced variation in quantitative traits due to physical (gamma rays), chemical (EMS) and combined mutagen treatments in soybean [Glycine max (L.). Merrill]. Soybean Genet. Newslett., 36 : 1-10.

Kharkwal, M.C. (1998). Induced mutation for improvement of protein in chick pea (Cicer arietinum L.). Indian J. Genet., 58: 61-68.

Kole, P.C. and Meher, S.K. (2005). Effect of gamma rays of some quantitative and qualitative characters in Zinnia elegans N.J. Jacguin in M1 generation. J. Ornamental Hort., 8(4): 303- 305

Patil Sudha D. (2014). Induction of mutation in commercial varieties of gladiolus using physical mutagen CO-60 gamma rays. International Journal of Advanced Research in Biological Sciences. Int.J.Adv. Res.Biol.Sci.2014; $1(6): 15-20$

Rather, Z.A., John, A. Q. and Zargarm G. H. (2002). Effect of 60Co gamma rays on Dutch iris. J. Orna. Hort., 5(2): 1-4.

Roychowdhury, R. and Tah, J. (2011). Chemical mutagenic action on seed germination and related agrometrical traits in M1 Dianthus generation. Curr. Bot., 2(8): 19-23.

Srivastava, P., Singh, R.P. and Tripathi, V.K. (2007). Response of gamma radiation (60Co) on vegetative and floral characters of gladiolus. J. Orna. Hort., 10(2): 135-136.

\section{How to cite this article:}

Priyanka Tirkey and Devi Singh. 2019. Effect of Physical and Chemical Induced Mutation on Different Character of Gladiolus (Gladiolus grandiflorus L.). Int.J.Curr.Microbiol.App.Sci. 8(11): 1510-1516. doi: https://doi.org/10.20546/ijcmas.2019.811.175 